\title{
OKSZANA JAKIMENKO \\ Fordítói tréning/szeminárium/tábor: mit lehet, és mit nem lehet megtanulni egy hét alatt?
}

A „Lehet-e megtanítani (megtanulni) a müfordítást?” kérdését rendszeresen felteszik a müfordítás elméletírói és a gyakorló müfordítók, mint ahogyan a felsőoktatási intézmények tanárai, a kiadók, maguk a müfordítók és az olvasók is. A fordítás mint önálló diszciplína az egyetemeken viszonylag új jelenség. A múlt század közepéig a fordítás hosszú évszázadokon keresztül az idegen nyelvek tanításának részét képezte (eleinte főként az ókori nyelvek tanításáét: az iskolások, majd az egyetemisták gyakorlatilag Európa minden országában, ahol az ókori nyelvek tanulása bekerült a kötelező tantárgyak közé, a latin és az ógörög nyelvek elsajátítása közben anyanyelvükre fordították az antik irodalom klasszikus müveit). A „tanítás közbeni fordítás” a 20. század közepén váltott át a fordítás tanításába, amikor igény mutatkozott nagyszámú ilyen irányú szakember képzésére. Ennek hátterében nem utolsó sorban a második világháború alatt és a háborút követően a globális együttmüködések nagyságrendjének megváltozása állt: a világháború idején és a háború utáni nemzetközi politikai és gazdasági kapcsolatok intézményrendszereiben tömegesen vettek részt olyan tolmácsok és fordítók, akik eredetileg az idegen nyelvek fakultásain tanultak, valamint a fordító-tolmács tevékenységhez kedvet érző, más szakmákhoz tartozó bilingvis értelmiségiek - a későbbiekben sokan közülük fordítóként-tolmácsként kezdtek el dolgozni, és szerte a világban fordítást-tolmácsolást tanítottak a nyelvi fakultások speciális fordító-tolmács szakjain. Hangsúlyozom, hogy ezeken a fordító-tolmács szakokon elsősorban a megfelelő szakterületek (politika, gazdaságtan, természettudományok, technika, stb.) szakfordítását tanították. Ugyanakkor még a 20. század első harmadában egy sor országban nyilvánvalóvá vált, hogy müfordítást is lehet, sőt kell tanítani.

E vonatkozásban példaértékünek tekinthető a Szovjetunióban 1918-tól, illetve a Vszemirnaja Lityeratura Kiadó megalapításától kialakult helyzet: a kiadó zavartalan tevékenységéhez ugyanis nagyszámú fordítóra volt szükség. A kiadó költészeti részlegének vezetője és kurátora, Nyikolaj Gumiljov, aki maga is nemzedéke egyik legjobb költészeti fordítója volt, nemcsak hogy újfajta közelítési módot hirdetett meg a költészet fordításához, hanem A költészet fordításáról címü esszéjében megfogalmazta a „fordító kilenc parancsolatát” is; Kornyej Csukovszkij pedig, aki ekkorra már elismert író és müfordító volt, $A$ prózafordítás című cikkében lefektette a prózafordítás alapelveit, és számba vette a benne előforduló tipikus hibákat. A két cikket tartalmazó brosúrát ${ }^{1}$ belső használatra szánták, könyvforgalomba nem került, Csukovszkij cikke

\footnotetext{
${ }^{1}$ Nyikolaj Gumiljov, Kornyej Csukovszkij, Principi hudozsesztvennovo perevoda, Petyerburg, Izd-vo Vszemirnaja lityeratura, 1919.
} 
azonban, amelyet a szerző a későbbiekben kiegészített, az alapja lett az orosz nyelvre fordító kezdő fordítók számára készült egyik legismertebb szövegnek, A magas müvészet címü könyvnek (1936; 1964).

A Vszemirnaja Lityeratura után a Szovjetunióban a müfordítók felkészítését célzó következő központosított intézményként az 1930-as évek elején létrehozott úgynevezett „Kaskin-iskolát” lehetne megnevezni: a Kaskin-követők írásai annak köszönhetően váltak ismertté, hogy közölték őket az Internacionalnaja Lityeratura (a mind a mai napig létező Inosztrannaja Lityeratura) című folyóirat lapjain. Az 1950-es évekig azonban minden hasonló müfordítói egyesülés (mint az Írószövetségen belül müködő szeminárium, vagy a legkülönfélébb felsőoktatási intézmények bölcsészkarain müködő fordítói szemináriumok és speciálkollégiumok), ahol müfordítást lehetett tanulni, tulajdonképpen „mühelyformában”, sajátos, zárt „céhformában” müködött, ahol a mesterek - vagyis a tapasztalt müfordítók - szemináriumokat vezetve, egymás fordításait megvitatva átadták készségeiket és tudásukat az ifjabb kollégáknak. Csupán 1955-ben, Moszkvában, az Irodalmi Főiskolán nyílik meg (ismereteim szerint elsőként a világon) Lev Ozerov vezetésével a müfordító szak, ahol kifejezetten a jövő müfordítóinak képzése folyik mind a mai napig. Jellemző, hogy a müfordító szakot kezdetben Fordítói Műhelynek nevezték, kiemelve ezzel is a képzés sajátosságait. Összehasonlításképpen bemutathatjuk Nagy-Britannia gyakorlatát, ahol a szépirodalmi müvek fordítását meglehetősen kései időkig leginkább csak a nyelvtanulás eszközeként fogták fel, ${ }^{2}$ és csak jóval később - az amerikai egyetemeket követve ${ }^{3}$ - került be a müfordítás a creative writing vagy a komparatisztika keretein belül az oktatási programba. ${ }^{4}$

Manapság egy fiatal orosz fordítónak, aki müfordítást akar tanulni, elvileg van miből válogatnia: egy sor felsőoktatási intézményben létezik műfordítói képzés (az Irodalmi Főiskolán is megmaradt a Müfordítói Tanszék), neves müfordítók indítanak müfordítói mühelyeket, amelyek müködhetnek különféle magániskolák keretein belül is (ilyen például a Moszkvában és Szentpétervárott müködő Creative Writing School íróiskolában Alekszandra Boriszenko és Viktor Szoszkin vezetésével működő müfordítói mühely), vagy lehetnek hagyományosabb kurzusok is (mint például az Azart Müfordítói Iskolában zajló müfordítói kurzusok). E képzések elsősorban a képzés formális jellegének mértékében különböznek egymástól: a felsőoktatási intézmények képzése magában foglalja egy sor filológiai tárgy tanulmányozását és a viszonylag pontosan elöírt metodológiát is; míg a mühelyek vezetői gyakran hangoztatják, hogy „mi

\footnotetext{
${ }^{2}$ Lásd erről például Nicholas Round, Monuments, Makars and Modules = Rimbaud's Rainbow: Literary Translation in Higher Education, eds. Peter Bush, Kirsten MalmkjÆr, Amsterdam - Philadelphia, John Benjamins, 1998, 11-20.

${ }^{3}$ Az Amerikai Egyesült Államokban az ilyen képzési programok az 1960-as években kezdtek megjelenni. ${ }^{4}$ A Nagy-Britanniában és az Egyesült Államokban folyó müfordítás-oktatásról részletesebben lásd Rebecca Hyde Parker, Professionalizing Literary Translation Education, Translation Journal, 2014/1. https:// translationjournal.net/journal/48literary.htm (Letöltés ideje: 2020. március 19.)
} 
gyakorló műfordítók vagyunk, és nem tartjuk fö feladatunknak az elmélet oktatását,", hangsúlyozva ezzel a müfordítás mühelyjellegét. De ugyanúgy képzésenként eltérhetnek a bemeneti és kimeneti követelmények, valamint a további perspektívák a munka folytatására. Létezik egy sor fordítói pályázat is (elsősorban kezdő müfordítók számára, olyanok, mint például a Puskin-ház kiírásában müködő Linyeckaja-pályázat), amelyeknek keretében rövid szemináriumokon a fordítási hibák elemzése zajlik.

A müfordítás oktatásában tapasztalható változások feltétlenül összefüggenek a könyvpiac átalakulásával, a fordított irodalom mennyiségi növekedésével és bizonyos társadalmi változásokkal is: az elmúlt néhány évtizedben a müfordítás viszonylag jól fizetett elitfoglalkozásból tömegfoglalkozássá vált (a szovjet időkben a fordító egy szerzői ívért nagyjából 200 rubelt kapott, miközben a havi átlagfizetés 120-130 rubel volt, ma pedig ez az arány úgy néz ki, hogy a fordító egy szerzői ívért 40006000 rubelt kap, miközben a havi átlagfizetés 44.000 rubelt tesz ki). Az elmúlt tízéves időszakban, 2008 és 2018 között a fordításban megjelent kiadványok aránya 11,5\%-ról 14,3\%-ra, a mennyisége pedig 12\%-ról 16,5\%-ra emelkedett az összes nyomtatott kiadványhoz képest. Ez azt jelenti, hogy csupán 2018-ban 16.765 cím jelent meg fordított irodalomból. Ennek jelentős részét (több mint 60\%-át) az angolból fordított irodalom tette ki, amelyet a franciából, olaszból és németből fordított irodalom követ. ${ }^{6}$ Alapjában véve ezek a nyelvek azok is, amelyekkel azokon a kurzusokon és szemináriumokon dolgoznak, amelyek arra hivatottak, hogy „bevezessék a szakmába” azokat, akik nem kifejezetten ezt a szakmát tanulták. A gyorstalpaló müfordítói oktatási programok nagy népszerüségnek örvendenek, és a tulajdonképpeni fordítási gyakorlatból gyakran alakulnak át olyan kurzusokká, amelyek egyszerüen csak kellemes, intellektuális ténykedést magukba foglaló időtöltéssé válnak, s olyan nagyszerű eseménnyel zárulnak, mint amilyen a közös kötet megjelentetése, amelyben a résztvevők nyomtatásban is viszontláthatják fordításukat. Hogy aztán az effajta kiadványok mennyire állják meg a helyüket a könyvpiacon, az már egészen más kérdés.

A fent leírt helyzet, mint már említettük, azokra a „nagy” nyelvekre vonatkozik, amelyekről alapvetően oroszra fordítanak: az angolul, franciául vagy németül tudók száma magas (ezek a nyelvek dominálnak az iskolai nyelvoktatásban is, és hagyományosan ezek a nyelvek a legnépszerübbek a felnőttkorban tanulásra választott nyelvek között is). ${ }^{7}$ Ha azonban a világirodalom úgynevezett „kis” nyelveiről ${ }^{8}$ beszélünk,

\footnotetext{
${ }^{5} \mathrm{http}: / /$ perevodasart.ru/about/ (Letöltés ideje: 2020. március 19.)

${ }^{6} \mathrm{Az}$ adatok forrása: Federalnoje agensztvo po pecsatyi i masszovim kommunikacijam. https://fapmc. gov.ru/rospechat.html; Rosszijszkaja knyizsnaja palata. http://www.bookchamber.ru/index.html (Letöltés ideje: 2020. március 19.) - A könyvpiacról szóló részletesebb elemzést lásd az Universzityetszkaja knyiga információs-elemző kiadványában és a Roszpecsaty kiadványaiban.

${ }^{7}$ Oroszországban manapság az európai nyelveket - kivéve a nemzetközivé vált angolt - elkezdte határozottan kiszorítani a kínai, ugyanakkor a kínaiból fordítani kívánó műfordítók számának emelkedéséről egyelöre nem beszélhetünk.

8 A „kis nyelv” kifejezés természetesen nem az adott nyelvet beszélők számára vonatkozik, hanem arra, hogy milyen mennyiségben fordítják ennek a nyelvterületnek irodalmát oroszra, és mennyi az e nyelvre specializálódott szakemberek száma Oroszországban.
} 
akkor sem ehhez hasonló mennyiségü nyelvtanárt, sem tanulót, sem ilyen változatos képzési formát nem tud az oroszországi oktatási piac (állami vagy magán, teljes vagy kiegészítő képzés) kínálni. Éppen emiatt a kevésbé népszerü nyelvekhez kapcsolódó „fordítói céhek” rendszerint csak a megfelelő profilú egyetemi tanszékek bázisán jönnek létre. Az ilyen nyelveket tanuló és a müfordítás iránt érdeklődő fiatal szakemberek vagy még egyetemi tanulmányaik során (az utolsó évfolyamokon), vagy az egyetem elvégzése után kapcsolódnak be a - gyakran rövid képzési ideig tartó - szemináriumok munkájába. A 2019. december 9-én, Moszkvában megrendezett XXI. Nemzetközi NonFiction Könyvkiállítás nyilvános szemináriumán sor került többek között annak látványos bemutatására, milyen különbségek léteznek a „nagy” és a „kis” nyelvekről történő müfordítás oktatásában. Míg egyfelől az angolból fordítók a szemináriumokon és kurzusokon való nem kötelező részvételre és a résztvevők alacsony szakmai felkészültségére panaszkodtak, és lényegében tagadták, hogy ezeken a tömeges gyorstalpalókon bármit is meg lehetne tanítani, addig a norvég, a svéd és a kínai irodalom fordítói a müfordítás-oktatás egy sokkal zártabb, céhjellegü formájáról számoltak be. ${ }^{9}$

A magyar irodalom oroszra fordítóinak felkészítése és „szakmai orientálása” manapság aszerint a modell szerint történik, amely a skandináviai, a kelet-európai, a keleti és más „kis nyelvek” fordítóira is érvényes. ${ }^{10} \mathrm{Az}$ alábbiakban bemutatásra kerülő szemináriumok és tréningek az elmúlt 10-20 év folyamán indultak, és segítik a kezdő müfordítókat abban, hogy közelebb kerüljenek a szakmához, és hírt adhassanak magukról az orosz könyvpiacon. Mindenképpen meg kell jegyeznünk, hogy a magyarról oroszra fordító műfordító - rendkívül ritka példány. Egyáltalán, Oroszországban a magyarból fordított könyvek száma nem túl magas, habár az utóbbi években nő az érdeklődés a magyar irodalom iránt, és a néhány magyarból fordító professzionális müfordító iránt továbbra is megvan a kereslet. A továbbiakban bemutatom a fiatal müfordítók számára elérhető képzési formákat - az egyszerű, bevezető jellegüektől kezdve a többnyelvü tematikus szemináriumokig.

A magyar nyelvet hagyományosan az egyik legnehezebben elsajátítható nyelvnek szokás tartani: nem-indoeurópai természete, agglutináló jellege, a grammatikai esetek és igeragozási formák sokasága és egyéb sajátosságai nehézségeket támasztanak az orosz anyanyelvű tanulók számára. A magyar szakos hallgatók a gyakorlatban csak a BA képzés második évének végére kezdenek el többé-kevésbé szabadon megszólalni magyarul (azokban az esetekben pedig, amikor a magyar nem a fö szakjuk, jelentősen későbben). A harmadik-negyedik évfolyamon, amikor már van némi elképzelésük a magyar irodalomról is (nincs minden olyan felsőoktatási intézményben magyar

\footnotetext{
${ }^{9}$ A szemináriumról készült videofelvétel az alábbi linken érhető el: https://www.youtube.com/channel/UCYICE_DzgZ0h8f9zgfHWN6w (Letöltés ideje: 2020. március 19.) ${ }^{10}$ A magyarról oroszra fordítás történetéről lásd például:

https://gorky.media/context/vechnoe-odinochestvo-vengerskoj-literatury (Letöltés ideje: 2020. március 19.) Ugyancsak erről a témáról tanulmány készül a Belgrádi Egyetem Hungarológiai Tanszéke fennállásának 25. évfordulója alkalmából rendezett konferencia anyagából is (Szerbia, 2019).
} 
irodalmi kurzus, ahol magyar nyelvoktatás folyik), a hallgatóknak lehetőségük nyílik részt venni a Magyar Kulturális Központ által szervezett müfordítói szemináriumokon. Figyelembe véve, hogy kevés azon felsőoktatási intézmények száma, ahol a BA képzés keretein belül magyart lehet tanulni (a Szentpétervári Állami Egyetem az egyetlen olyan intézmény, ahol mesterképzés is zajlik), a résztvevők száma általában nem túl magas, többségük nem rendelkezik semmilyen müfordítói tapasztalattal, nem mindegyiküknek anyanyelve az orosz, ami számukra még tovább nehezíti a magyarról oroszra történő fordítás feladatát: úgyhogy az egyhetes, pláne a három-négynapos kurzusok nem teszik lehetővé, hogy behatóan lehessen foglalkozni az orosz nyelvre történő fordítás problémáival. A szemináriumok során a résztvevők különféle típusú szépirodalmi szövegekkel ismerkednek meg, megpróbálják azokat lefordítani, megbeszélik a szemináriumvezetőkkel a megoldásaikat, néha pedig - ha ezt a felkészültségük lehetővé teszi - olyan nagyobb lélegzetü szövegek részletein vagy kisebb szövegeken dolgoznak, amelyek bekerülhetnek későbbi publikációs kötetekbe, mesterkurzus vagy alkotói találkozó keretében beszélgethetnek a magyar irodalmat fordító elismert szakemberekkel, részt vesznek a Magyar Kulturális Központ rendezvényein, és megismerkedhetnek olyan kiadók szerkesztőivel, amelyek magyar irodalmat is kiadnak. Korábban, amíg működött a kulturális központ könyvtára, a résztvevők használhatták az ottani könyveket, elemezhették idősebb kollégáik megjelent fordításait. Ez a forma, minden korlátozottsága és kaleidoszkópikussága ellenére, lehetőséget ad az ifú hungarológusoknak arra, hogy megismerkedjenek más városokból (hagyományosan Moszkvából, Szentpétervárról és Izsevszkből) érkező leendő kollégáikkal, bővítsék Magyarországról és a magyar kultúráról szerzett ismereteiket.

Ha az efféle bevezető jellegű szeminárium meglehetősen szabad formában zajlik, akkor, véleményem szerint, a felkészítés következő fokát célszerü izoláltabb környezetben megrendezni, ahol a résztvevők - akik már viszonylag szabadon használják a magyar nyelvet - összpontosíthatnak egy konkrét szöveg fordítására, és könyvtári kutatómunkát is tudnak végezni. A magyar nyelvről fordítás esetében erre kiváló lehetőséget nyújt a balatonfüredi Magyar Fordítóház, ahol mélyebben bele lehet merülni a müfordítás fortélyaiba. Ebben az esetben is a résztvevők anyanyelve továbbra is az orosz, a szemináriumvezető kiválasztja egy magyar szerző szövegét vagy szövegeit, konkrét feladatokat ad ki, és a szemináriumot a feladatok megoldásának függvényében vezeti. Amellett, hogy a résztvevők használhatják a gazdag könyvtárat, könyvújdonságokkal ismerkedhetnek meg (a Fordítóház rendszeresen frissíti az újdonságokból létrehozott kiállítást), újságokat és folyóiratokat olvashatnak, amelyek nem érhetők el teljes verziójukban az Interneten, olyan alkotóházi légkörbe kerülnek, ahol minden a produktív munkát segíti. A Fordítóház könyvtárában fellelhető magyar irodalmi művek különböző nyelveken megjelent fordításai pedig ösztönzik a hallgatókat, és segítséget adnak abban, hogy milyen könyveket válasszanak fordításra a jövőben. Egy ilyen szemináriumon való részvétel általában azt feltételezi, hogy a résztvevő a Fordítóházban eltöltött idő után is folytatja a megkezdett munkát. Mindennek 
eredménye a fordítás publikálása - fóként nyomtatott vagy elektronikus folyóiratokban, ritkábban önálló könyvben. A Fordítóház szemináriumainak résztvevői közül többen is jelentkeznek a későbbiekben a Balassi Intézet müfordítói szemináriumaira.

A foglalkozások hatékonysága és az információszerzés szempontjából még intenzívebb formának tekinthető a fordítótábor. Esetünkben az efféle táboroknak két formájáról beszélhetünk. Kétnyelvü táborról, amelyben párhuzamosan két fiatal fordítócsoport dolgozik: magyar fiatalok, akik orosz irodalmat fordítanak, és orosz fiatalok, akik magyar irodalmat fordítanak. 2013 óta (a magyar fiatalok számára 2012 óta) ilyen tábor zajlik a Lakiteleki Népfőiskolán. Mint a megelőző formában, a résztvevők itt is konkrét szövegen vagy szövegrészleten dolgoznak, amelyet a későbbiekben tökéletesítenek, és előkészítenek a közös kötetben történő publikálásra, vagy egyes esetekben az önálló kötetben való megjelentetésre. A lakiteleki müfordítótábor eredményeképpen említhetők a Rudomino Könyvtár Magyar stílus című könyvsorozatában megjelent olyan kötetek, mint a Csáth Géza novelláit tartalmazó A varázsló kertje című válogatás (Сад чародея, 2013), vagy a Magyarország - Magyarország határain túl (Венгрия за границами Венгрии, 2015) címü kötet. Ugyancsak ebben a körben említhetjük meg Kondor Vilmos Budapest noir (Будапештский нуар) címü könyvét is, amely 2020-ban jelenik meg egy olyan fiatal müfordító, Ljudmila Kulagova fordításában, aki többször is részt vett a lakiteleki müfordítótáborban, és a könyv első részletét éppen az egyik táborban fordította le. Ily módon a táborban folyó munka előkészítő jelleget ölt, és azt feltételezi, hogy a résztvevők folytatják a szövegek fordítását a tábor programjának lezárulta után is. A résztvevők a kifejezetten fordításelméleti és fordítástechnikai foglalkozások mellett hallgathatnak előadásokat irodalomról, magyar és orosz történelemről, filmművészetről, színházművészetről, képzőművészetről - vagyis alkalmuk nyílik a fordításhoz szükséges látókörük szélesítésére. E forma kétségtelen előnyét jelenti a „kölcsönös motiváció” effektusa: az ismerkedés azokkal a kollégákkal, akik a nyelvpár másik felével, a másik irányba történő fordítással foglalkoznak, ami lehetővé teszi, hogy másként szemléljék a konkrét nyelvpár sajátosságait, másként fogják fel azokat a problémákat, amelyek a fordítás során felmerülnek, valamint alkalom nyílik arra is, hogy szakmai kapcsolatokat alakítsanak ki a jövőre nézvést. A táborban a foglalkozásokat kiváló műfordítók, kulturológusok, irodalomés művészettörténészek vezetik. Az elmúlt nyolc év folyamán a tábor szervezését és tartalommal való megtöltését változatlan sikerrel Goretity József valósította meg, akinek köszönhetően lehetővé vált, hogy az orosz és magyar hallgatók párhuzamosan vegyenek részt a táborban.

A fordítói tábor másik formája a többnyelvű tábor. E formátumban a fiatal fordítótól még nagyobb önállóságra van szükség, nem is beszélve a két nyelv - a forrásnyelv és a célnyelv - ismeretének magasabb szintjéröl. 2019-ig a magyar irodalom fiatal fordítói, akik különféle nyelvekre fordítottak, részt vehettek a József Attila Kör müfordító táborában, ma viszont ezt a tábort már a Palimpszeszt Kulturális Alapítvány szervezi, de a tábor struktúrája ugyanaz maradt: a résztvevők olyan író szövegein 
dolgoznak, aki lehetőség szerint maga is részt vesz a táborban, és találkozik a müfordítókkal. Itt is elhangzanak előadások a magyar prózáról és költészetről, amelyeket ugyanúgy, mint Lakiteleken, kiváló irodalomtörténészek és kritikusok tartanak; lehetőség nyílik például arra, hogy a résztvevők találkozzanak a vezető magyar irodalmi hetilap, az Élet és Irodalom szerkesztőivel. Az a tény, hogy a résztvevők ugyanazt a szöveget különféle nyelvekre fordítják, különleges alkalmat nyújt arra, hogy az adott szöveget a maga teljességében, különböző nézőpontokból vizsgálhassák, és megfogalmazhassák azokat az univerzális fordítási problémákat, amelyek egy adott célnyelvre aktualizálhatók. Ily módon a többnyelvű müfordítói tábor még magasabb szintje a müfordítás tanulásának, amely még önállóbb munkára készít fel.

E formának létezik egy másik variánsa is, amelyben továbbképzési céllal gyakran részt vesznek „felnőtt”, a müfordítói piacon már aktívan dolgozó kollégák is. Itt tematikus szemináriumról van szó, amely egy konkrét müfajhoz tartozó szövegek fordítását kínálja. Példaként említhetjük a drámafordítói szemináriumot (korábban ez a Kortárs Drámafesztiválhoz kapcsolódott, az utóbbi időben azonban kevéssé rendszeresen zajlik). A szeminárium keretei között a műfordítók nemcsak találkoznak az adott drámák szerzőivel, hanem megnézik a drámákból készült előadásokat is: ily módon nemcsak új drámaszövegekkel ismerkedhetnek meg, hanem pontosíthatják azok megértését is, hiszen az audiovizuális szöveggel folytatott munka más, non-verbális információkat is igényel. Ilyen tematikus szemináriumok más müfajok - például gyermekirodalom, detektívirodalom - köré is szerveződnek.

A különféle műfordítói szemináriumok, nyári táborok, tréningek természetesen nem válthatják ki azt az áldozatos munkát, amelyet a fordítónak saját képességei fejlesztése érdekében önállóan el kell végeznie. A hasonló rendezvényeken való részvétel időnként hamis képzeteket válthat ki a fiatal müfordítókból a felkészültségüket illetően. Az effajta rendezvényeken elvégzett munka a legtöbb esetben még nem jelent kész müfordítást: a résztvevők azonban korántsem mindig értik meg, hogy az egy hét alatt elkészített fordítás további csiszolást és pontosítást igényel. A szemináriumvezetőknek nem könnyü - hacsak nem közvetlen tanítványaikról van szó - nyomon követni és további munkára ösztönözni a résztvevőket a rendezvény lezárulta után is. E „belső” problémán kívül felmerülnek még külső tényezők is. A kiadók gyakran gyanakvással fogadják az ifú műfordítókat, maguk a müfordítók pedig a szeminárium vagy a nyári tábor jóindulatú és komfortos légköre után belecsöppennek a piaci viszonyokba, ahol aktivitást, kezdeményezőkészséget kell mutatniuk, és a lojális tanári kritika után fel kell készülniük a kemény bírálatokra is. Van egy csomó olyan kérdés is, amely a kiadói politikával és mint ennek következményével, a műfordítói perspektíva szükülésével áll összefüggésben. És végül, az oroszországi hungarológusképzés jellegéből adódóan nem minden hungarológusnak orosz az anyanyelve, ők pedig nem tudnak versenyképesek lenni az orosz müfordítói piacon.

Összességében elmondhatjuk, hogy a müfordítói szemináriumok és táborok képesek fenntartani a fiatal hungarológusok érdeklődését a magyar irodalom oroszra 
fordítása iránt, ugyanakkor semmiképpen sem tarthatók elegendő eszköznek arra, hogy teljes értékü felkészítésként szolgáljanak, és - a müfordítók és a kiadók közötti szisztematikus, intézményi kapcsolatrendszer hiányában - „meggyökereztessék” az ifjú müfordítókat a szakmában. Mindazonáltal a különféle müfordítói képzések lehetővé teszik, hogy ne szakadjon meg a hagyomány, hogy megörizhessük azt, amit „fordítói iskolának” szokás nevezni - ha másként nem, legalább „alvó sejt” formájában.

GoRETity József fordítása

\author{
OKSZANA JAKIMENKo \\ egyetemi docens \\ Szentpétervári Állami Egyetem \\ oxana.yakimenko@gmail.com \\ Translation Training/Seminar/Camp: \\ What Can and Cannot Be Learnt in One Week?
}

\begin{abstract}
The paper studies the question of the possibility of teaching and learning translation, especially literary translation. First, it examines the theoretical principles of whether the necessary skills for literary translation can be acquired, and what possible forms are there to teach and learn translation. The theoretical standpoint of the author is based upon the training of those Russian young people who are in a special circumstance in Russia, since they translate the literature of a "small language", Hungarian, to Russian. The author analyses various translator trainings besides university education: translator trainings, literary translation seminars, master courses, and literary translation camps.
\end{abstract}

Keywords: Hungarian language teaching in Russia, the reception of Hungarian literature in Russia, learnability of literary translation, translator trainings

DOI: 10.37415/studia/2020/1-2/139-146.

Open Access: Creative Commons Attribution 4.0 International (CC BY 4.0) (c) (i) 